\title{
CIJFERS NAAR AANLEIDING VAN DE DUITSCHE RIJKSBANK POLITIEK.
}

In de groote crisis, waaraan het oeconomisch leven op het oogenblik bloot staat, is er wellicht geen enkel land, waar de voorbereiding daartoe meer in details gereed gemaakt is dan in Duitschland. Niet alleen werden maatregelen beraamd, die in oorlogs- of crisis tijden uitgevoerd zouden moeten worden, maar ook op alle instellingen, van belang voor het oeconomisch leven, werd aandrang uitgeoefend, dat zij zich reeds in normale tijden zóó zouden inrichten, dat zij aan eene dergelijke crisis het hoofd zouden kunnen bieden. Deze maatregelen hebben het aanzijn gegeven aan eene gewijzigde opvatting van de taak eener centrale circulatiebank. Hieronder zijn eenige gegevens verzameld, betrekking hebbende op deze maatregelen. Voor een groot deel zijn zij ontleend aan de jaarverslagen der Rijksbank, aan het Referaat van Dr. Helfferich op den Bankiersdag van 1912 in München en aan tijdschriftenartikelen en brochures o. a. van Plenge en van Lansburgh. De toelichting is voornamelijk bedoeld als aanvulling van het gegeven cijfermateriaal, al kon niet steeds een partijkiezen vermeden worden.

Volgens de Duitsche Bankwet van 1873 had de Duitsche Rijksbank eene drieledige taak:

$1^{\circ}$. Regeling van den geldomloop in het Rijksgebied.

$2^{\circ}$. Het betalingswezen te vergemakkelijken.

30. "Etwa verfügbares Kapital nutzbar zu -machen."

Tot 1907 heeft de Duitsche Rijksbank zonder uiterlijke moeilijkheden aan alle drie eischen gelijktijdig kunnen voldoen, waarbij de plaats, als eenigst zekere groote kredietbron, welke de Rijksbank vooral in den aanvang innam, haar er toe gebracht heeft, zich tot taak te stellen om alle credietaanvragen, welke aan formeele eischen voldeden, 
in te willigen. Op deze wijze werd het „etwa verfügbares Kapital" wel eenigzins uitgebreid. De Bank kon daartoe straffeloos overgaan, doordat hare ongedekte biljettencirculatie haar een elastisch werkkapitaal gaf, slechts begrensd door den eisch eener $33 \frac{1}{3}$ pCt. dekking.

Gemiddeld wisselbezit van de Rijksbank in de jaren:

$$
\begin{aligned}
& 1876 \text {. . . . . . } 402.909 .000 \text { R. M. } \\
& 1877 \text {. . . . } 366.814 .800 \text { " } \\
& 1880 \text {. . . . . . } 345.726 .000 \text { " } \\
& 1885 \text {. . . . . . } 372.746 .000 \text { " } \\
& 1890 \text {. . . . . } 534.142 .000 " \\
& 1895 \text {. . . . . } 573.924 .000 \text { " } \\
& 1910 \text {. . . . . 994.446.000" } \\
& 1912 \text {. . . . . } 1.238 .325 .000 " \\
& 23 \text { Juli } 1914 \text {. } \\
& 31 \text { Juli } 1914 \text {. . . . . . 2.081.075.000" }
\end{aligned}
$$

Van 1876 tot 1913 zien wij eene vermeerdering van bijna $300 \mathrm{pCt}$. van het gemiddeld wisselbezit. Op zichzelf behoeft dit niets onrustbarends te hebben, daar de uitbreiding van handel en industrie daar vrijwel paralel mede gegaan is. Van grooter belang is de metaaldekking. $\mathrm{Na} 1890$ zien wij eene geleidelijke achteruitgang, die pas na 1910 tot staan is gebracht. Deze achteruitgang had niet alleen plaats in de metaaldekking, maar bovendien in de nog belangrijker gouddekking harer opvraagbare gelden.

Gemiddelde dekking van biljettenomloop en deposito's in :

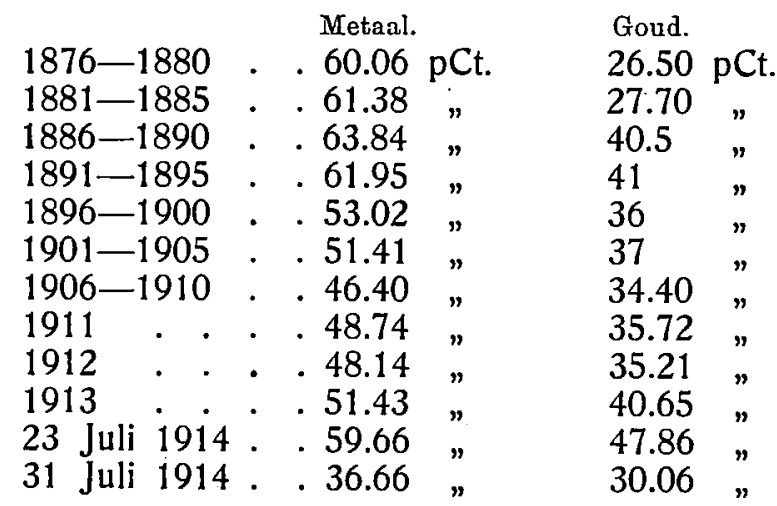

(De metaaldekking van 31 Juli wordt begunstigd door het overbrengen van den metaal oorlogschat ter grootte van 205 Millioen Mark naar de Rijksbank.) 
Door de ruime definitie aan „etwa verfügbares Kapital” gegeven, liep de Rijksbank gevaar, dat zij in crisisdagen minder goed aan groote kredietaanvragen het hoofd zoude kunnen bieden.

Gemiddelde.

Metaal.

Biljettenoml.

Wissels.

1891-1895

924.375.400

1.007.441.200

554.141 .000

$1896-1900$

851.398 .600

$1.114 .821: 600$

724.438 .000

$1901-1905$

939.637 .600

1.258 .571 .000

839.951 .000

1906-1910

971.101 .200

1.514.515.200

995.010 .200

1910

1.055 .803 .000

1.605.882.000

994.446 .000

1911

1.129 .242 .000

1.663.615.000

1.077 .777 .000

1912

1.203.595.000

1.781 .999 .000

1.238.325.000

1913

1.350 .664 .000

1.958.173.000

1.135 .986 .000

23 Juli 1914

1.692 .000 .000

1.891 .000 .000

751.000 .000

31 Juli 1914

1.528 .026 .000

2.909.000.000

2.081 .000 .000

Nemen wij de gemiddelden van perioden van 5 jaar, dan zien wij, dat de Rijksbank tusschen 1891 -'95 en 1906-'10 een bedrag van 507.074.000 R. M. meer aan biljetten in omloop heeft weten te brengen. Daar tegenover staat slechts eene metaalvermeerdering van 46.725.800 R. M. Het grootste deel der vermeerderde biljettencirculatie is gebruikt voor rendabele belegging. Niet alleen het kredietverkeer van de Rijksbank heeft eene groote uitbreiding ondergaan, het particuliere kredietwezen is daarnaast met nog grooter sprongen voorwaarts gegaan. Van 1895 tot 1910 stegen de totale vreemde gelden bij de kredietbanken, volgens schatting van 1769.4 millioen Mark op 9122.9 millioen Mark, dus omstreeks 400 pCt. Dit particuliere credietwezen heeft zich uitgebreid, wetende steeds op de hulp van de Rijksbank te kunnen steunen. Neemt men verder in aanmerking de uitbreiding van de baargeldsparende methoden van betalingen, dan is het duidelijk, dat de eischen waaraan de Rijksbank moet kunnen voldoen nog meer zijn vermeerderd dan hare balansen zouden doen vermoeden.

Uit nevengaanden staat blijkt duidelijk aan welke groote schommelingen, de eischen onderhevig zijn, aan haar gedurende een jaarsverloop gesteld, welke schommelingen van 1875 tot 1912 eene steeds grootere kracht verkregen hebben. 


\begin{tabular}{|c|c|c|c|c|c|c|}
\hline & \multirow{2}{*}{\multicolumn{3}{|c|}{$\begin{array}{l}\text { Wissels, en beleeningen } \\
\text { in Millioenen Marken. }\end{array}$}} & \multicolumn{3}{|c|}{ Biljetten omloop } \\
\hline & & & & in & llioenen & Marken. \\
\hline & Hoogst & Laagst & Spanning & Hoogst & Laagst & Spanning \\
\hline 1876 & 533 & 380 & 153 & 775 & 620 & 155 \\
\hline 1880 & 500 & 340 & 160 & 815 & 680 & 135 \\
\hline 1890 & 810 & 500 & 310 & 1130 & 885 & 245 \\
\hline 1900 & 1235 & 745 & 490 & 1410 & 1005 & 405 \\
\hline 1907 & 1860 & 920 & 940 & 1885 & 1275 & 610 \\
\hline 1911 & 1910 & 883 & 1027 & 2295 & 1372 & 923 \\
\hline 1912 & 2210 & 1030 & 1180 & 2519 & 1487 & 1032 \\
\hline 1913 & 1843 & 900 & 943 & 2593 & 1711 & $8 \dot{8} 2$ \\
\hline
\end{tabular}

Het bijna algemeen vertrouwen, dat men in de Duitsche Rijksbank gesteld had, werd in 1907 aan het wankelen gebracht. Voordien had het verminderde weerstandsvermogen van de Rijksbank nog geen ongerustheid veroorzaakt. In het gedenkschrift in 1900 door de Rijksbank uitgegeven wordt dan ook met trots vermeld, dat nog nimmer door haar eene, aan formeele eischen voldoende, kredietaanvrage geweigerd is geworden. De bizonderheden van die crisisdagen zijn nog welbekend, en wij kunnen volstaan met te vermelden, dat van uit Europa groote hoeveelheden edel metaal hun weg vonden naar New-York. Deze metaalverzendingen veroorzaakten een scherpen weerslag op de Duitsche geldmarkt.

Getrouw aan hare gewoonte, verhoogde de Rijksbank haar disconto van $5 \frac{1}{2}$ op $7 \frac{1}{2}$ pCt., om daardoor te trachten de aan haar gestelde eischen binnen beperkte grenzen te houden. Desondanks daalde de metaaldekking van den biljettenomloop tot $37 \mathrm{pCt}$. Zelfs in de meest conservatieve finantieele kringen drong toen het bewustzijn door, dat er iets aan de politiek van de Rijksbank haperde en men wierp jaloersche blikken naar Engeland, dat blijk gegeven had een grooter weerstandsvermogen te bezitten. Vanaf het oogenblik, dat de overtuiging van de noodzakelijkheid van wijziging harer politiek zich gevestigd had, ontbrandde een felle strijd over de oorzaken van dezen toestand en de middelen ter verbetering. Eenerzijds werd de schuld geworpen op het misplaatst geven van credieten door de verschillende banken, ten koste hunner liquiditeit, anderzijds op de leiding van de Rijksbank, die alleen mechanisch 
hare disconto politiek toegepast had. Deze strijd was in Augustus van dit jaar nog niet to eene beslissing gekomen.

De Rijksbank begreep toen, dat zij naar meerdere middelen moest 'omzien, dan naar de van oudsher toegepaste disconto politiek indien zij het metaal niet alleen naar zich toe wilde trekken, maar het ook wilde behouden. Het zoude ons te ver voeren al de toegepaste middelen hier te bespreken, slechts van enkelen volgt hieronder eene korte vermelding.

Op den Bankiersdag in 1912 te München gehouden, wijst de bekende Directeur van de Deutsche bank, Dr. Karl Helfferich er op, dat het beeld hetwelk de Duitsche Rijksbankstaten aanbieden, heel wat opgewekter wordt, wanneer men de buitenlandsche wisselportefeuille en het buitenlandsch tegoed bij de metaaldekking rekent.

Gemidddelde: buitenlandsche wissels en tegoed in pCt. van

\begin{tabular}{|c|c|c|c|c|}
\hline & & & biljelten & $\begin{array}{l}\text { dagelijksche oprraagbare } \\
\text { gelden }\end{array}$ \\
\hline $1891-190$ & & . & 0.8 à 1.8 & 0.6 à 2.2 \\
\hline 1905. & & . & . 3.6 & 2.5 \\
\hline 1906 & . & . & . 4.5 & 3.3 \\
\hline 1907 & $\cdot$ & . & - 3.7 & 2.7 \\
\hline 1908 & . & . & . 6.2 & 4.4 \\
\hline 1909 & . & . & .11 .1 & 7.6 \\
\hline 1910 & . & . & .14 & 10 \\
\hline 1911 & . & $\cdot$ & . 12.1 & 8.2 \\
\hline
\end{tabular}

(Bovenstaande staat kan niet voortgezet worden, daar de daartoe noodige gegevens, voor zooverre bekend, niet gepubliceerd worden:)

Deze z.g. Devisen politiek is pas na 1907 van eenig belang geworden. Uit de door Dr. Helfferich gegeven getallen blijkt, dat deze Devisen te samen met het buitenlandsch tegoed in 1907 gemiddeld slechts 3.7 pCt. van de biljettencirculatie bedroeg, tegenover $12.1 \mathrm{pCt}$. in 1911.

Van verschillende zijden is er twijfel geopperd, of deze Devisen en buitenlandsche tegoeden wel, al is het slechts theoretisch, bij den metaalvoorraad gerekend mogen worden. Zelfs al neemt men alleen Devisen op die landen, waarvan men de zekerheid meent te hebben ze in goud ingelost te krijgen, dan nog zijn ze slechts een recht op goud. Zulk een recht op goud kan nimmer met goud gelijkgesteld 
worden. Andere landen daarentegen bezitten weder Devisen op - Duitschland, welk wederzijdsch bezitten elkanders werkkring kunnen neutraliseeren. Of bij de groote crisis van dit jaar de Devisen portefeuille veel metaal naar. Duitschland heeft doen vloeien mag dan ook met recht betwijfeld worden. Toch moet men hare beteekenis niet onderschatten. Deze beteekenis moet men dan ook minder zoeken in tijden van internationale crisis dan wel in meer normale tijden, wanneer door hunne uitgifte of aankoop het goudverkeer in de gewenschte richting beinvloed kan worden, terwijl zij dan ook als regulator van de betalings balans kunnen dienen. Deze hulp is slechts eene tijdelijke. Door aankoop stijgen ${ }^{1}$ ) de wisselkoersen en komt men nader tot gouduitvoer. Deze uitvoer moet weder door tijdigen verkoop voorkomen worden.

Eene groote Devisen portefeuille van de Duitsche Rijksbank onttrekt geld aan de binnenlandsche geldmarkt. Het bezit moet toch zoo groot zijn, dat zij een tijdelijk deficit van de betalingsbalans herstellen kan.

Onze conclusie is dus dat de Devisen, hoogstens als een zeer liquide bezit aangemerkt kunnen worden, een bezit dat alleen bij ongestoorde functioneering der internationale geldmarkt gerealiseerd kan worden en welks grootste nut gelegen is in het stabiliseeren van de wisselkoersen tusschen de beide goudpunten.

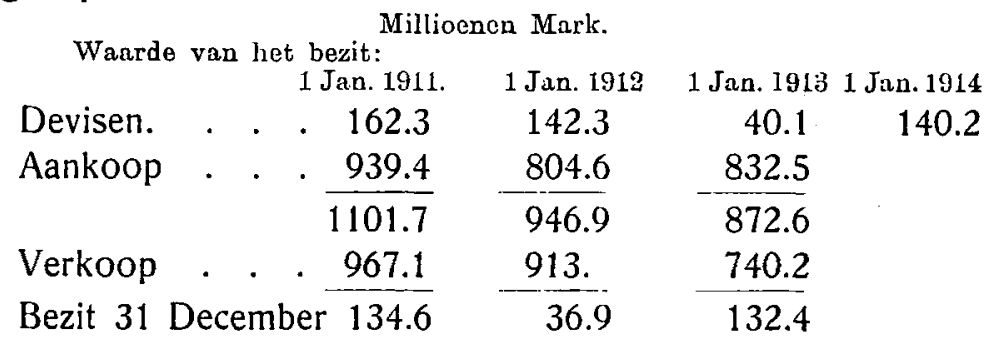

In de jaarverslagen ontbreekt eene opgave van het buitenlandsch tegoed. Uit de gegeven cijfers blijkt, dat in ieder geval gedurende het jaar 1912 de wisselkoersen een evenredigen aankoop naar gelang van de gerealiseerde Devisen niet toelieten. In het verslag wordt opgemerkt: „Die Reichsbank stand den verstärkten Anforderungen, dank

1) Lansburgh wijst er terecht op dat de meeste voorstanders van Devisen-politiek dit vergeten. 
wesentlich höheres Goldvorräte und Devisenbestände noch besser gerüstet gegenüber als im Vorjahre." Wellicht wijst dit op 'een hooger buitenlandsch tegoed verkregen bij het vervallen der Devisen. Uit de gegeven cijfers blijkt toch een gemiddeld lager Devisen bezit dan in het voorafgaande jaar.

Er zijn twee mogelijkheden:

A. De Devisen zijn gebruikt ter beinvloetding der wisselkoersen in goudaantrekkende riciting; er wordt geen buitenlandsch tegoed gevormd. In dat geval zouden zij alleen bij nog grooter voorraad in staat geweest zijn een tegenwicht te vormen aan de groote geldopvragingen, vooral van Frankrijk. Nu konden zij slechts eene tijdelijke hulp bieden.

B. $\mathrm{Zij}$ zijn gebruikt tot het vormen van een buitenlandsch tegoed, om op die wijze desgewenscht den metalvoorraad te versterken.

De invloed van het buitenlandsch tegoed kan uit het verslag niet opgemaakt worden. Aanvangende met het verslag over het jaar 1912, wordt het Devisen bezit van 31 December voor het eerst gedetailleerd 'opgegeven.

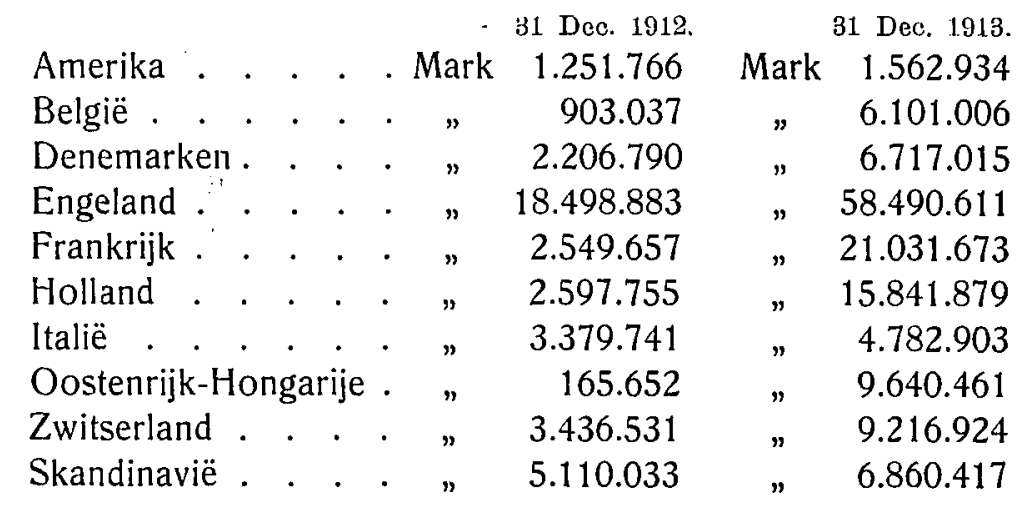

Uit slechts twee jaren kunnen moeilijk conclusies getrokken worden. Eigenaardig mag zeer zeker genoemd worden het bezit van wissels op Oostenrijk-Hongarije, tenzij deze alleen gebruikt worden ter afwering van goudafvloeiïngen.

Naast deze z.g. Devisen politiek zocht de Rijksbank versterking van haar metaalvoorraad te verkrijgen door het uitgeven van biljetten in coupures, kleiner dan 100 Mark. 
Zoo kreeg in 1906 de Rijksbank vergunning tot het uitgeven van biljetten van 25 en 50 Mark tot een maximum bedrag van 300 Millioen Mark. Wilde de-Rijksbank nu door zulk eene vermeerderde biljettencirculatie haren metaalvoorraad vermeerderen, dan moesten deze biljetten niet alleen in de circulatie gebracht worden, maar daar ook blijven. Een prikkelende invloed op eene vermeerderde biljettencirculatie bleek toch dringend noodig.

Gemiddelde jaarsomloop van 1000 Mark biljetten.

\begin{tabular}{|c|c|c|c|c|c|c|c|c|}
\hline 1889 & & & . & . & & 410.5 & Millioen & Mark \\
\hline 1893 & . & & . & . & & 350.5 &, & , \\
\hline 1895 & : & & . & . & & 470.3 & $"$ & $"$ \\
\hline 1900 & . & & . & . & - & 381.4 & $"$ & $"$ \\
\hline 1905 & . & & . & . & & 424.2 & ” & n \\
\hline 1910 & . & & . & . & & 371.0 & $"$ & $"$ \\
\hline 1911 & $\therefore$ & & . & . & & 305.2 & $"$ & $"$ \\
\hline 1912 & . & & . & . & & 306.3 & $"$ & $"$ \\
\hline 1913 & . & & . & . & & 291.6 & ” & " \\
\hline
\end{tabular}

Door de bankconcentratie en door de baargeldsparende betalingsmethoden; werden zoowel de werkingssfeer van de 1000 Mark als van de 100 Mark biljetten (in verminderde mate) gedeeltelijk beperkt. Slechts door de kleinere coupures zoude het verloren terrein herwonnen kunnen worden.

Niet alleen was het door deze uitgifte mogelijk meer biljetten in circulatie te houden, maar men mocht met recht hopen, dat zij in crisistijden minder dan de grootere coupures ter inwisseling zouden aangeboden worden. Zij drongen in het gebied der goudgeld betalingen en zouden dus de 20 Markstukkelı eerder naar de kluizen der Rijksbank doen toevloeien. Men verwachtte toch, dat zij een onmisbaar deel der geldcirculatie zouden vormen. In Augustus j.l. heeft deze hoop zich echter niet geheel bewaarheid, daar juist de houders der kleinere coupures het eerst op inwisseling aandrongen. (Vooral in ons land.)

Hunne beteekenis bleek reeds dadelijk in het crisisjaar 1907. Toen in December 1907 de metaaldekking der biljetten op $37 \frac{1}{2}$ pCt. gezonken was, wist de Rijksbank alleen boven de gevreesde $33 \frac{1}{3} \mathrm{pCt}$. te blijven, door in die maand, 85 Millioen van dergelijke biljetten uit te geven. 


\begin{tabular}{|c|c|c|c|c|c|}
\hline & & $\begin{array}{c}\text { Baarde } \\
\text { bíljet }\end{array}$ & $\begin{array}{l}\text { kking } \\
\text { ten. }\end{array}$ & $\begin{array}{l}\text { Baardekking } \\
\text { coupures op } \\
\text { omloop kleine }\end{array}$ & $\begin{array}{l}\text { - kleine } \\
\text { biljetten - } \\
\text { coupurés.'1) }\end{array}$ \\
\hline 31 December & 1906. & 40.33 & pCt. & 37.17 & pCt. \\
\hline 31 & 1907. & 41.33 & tres & 30.72 & $"$ \\
\hline 31 & 1908. & 52.56 & ( & 44.62 & $"$ \\
\hline 31 & 1909 & 46.87 & $"$ & 44.08 & $"$ \\
\hline $31 \quad$ & 1910 . & 47.01 & $n$ & 38.47 & $n$ \\
\hline 1. Maart & 1911. & . $\quad 56.70$ & $n$ & 50.40 & $"$ \\
\hline 30 Juni & 1911. & . $\quad 59.88$ & $n$ & 53.72 & ln \\
\hline 30 September & 1911. & . 44.89 & $"$ & 35.06 & $"$ \\
\hline 1 December & 1911 & . 46.14 & $"$ & 35.66 & $"$ \\
\hline 1 & 1912 & . 41.80 & " & 26.32 & $"$ \\
\hline & 191 & 55.78 & $"$ & 40.01 & " \\
\hline
\end{tabular}

Uit bovenstaande staat, gedeeltelijk overgenomen uit de "Frankfurter Zeitung", blijkt de groote beteekenis dezer kleine coupures, al is hier lichtelijk overdreven de voorstelling, dat jeder klein biljet, een gelijk metaalbezit vertegenwoordigt. Neemt men de verslagen van de laatste drie jaren, dan vindt men:

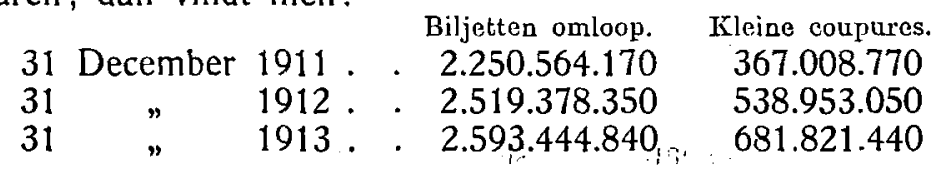

Tegenover eene vermeerdering van den biljettenomloop van globaal 340.000 .000 R. M. staat eene vermeerdering der circulatie van kleinere biljetten van omstreeks 320.000 .000 R.M. Bijna de geheele meerdere biljettenomloop valt ten bate van de kleine coupures te boeken. Einde September 1911 . overschreed de omloop aan kleine biljetten het gestelde maxmum van 300 Millioen Mark, welk maximum pas op 21 Januari 1913 officieel werd opgeheven.

Aan de passiefzijde harer balans heeft de Rijksbank naast de biljettenomloop nog de z.g. Giroguthaben. Vermeerdering daarvan kan haar in staat stellen haar actiefpost metaal te verhoogen. Eigenaardig is daarbij na te gaan hoe deze Giroguthaben zich b.v. gedurende het tijdperk van 1895-1911 gehouden hebben. De metaalvoorraad is met globaal 117 Millioen Mark vermeerderd, de wissels en beleeningen met

1) Hierbij is gerekend dat iedere kleine coupure in circulatie, een even groote waarde aan metaal naar de Rijksbank gebracht heeft, zoodat de kleine coupures zoowel van het metaal bezit als van de biljetten circulatie afgetrokken zijn. 
500 Mill. 'Mark, in totaal op deze posten dus eene vermeerdering van omstreeks 617 Mill. Mark. De biljettenomloop is met 568 Mill. Mark vermeerderd en de Giroguthaben met 144 Mill. Mark, in totaal dus 712 Mill. Mark. De totale vermeerdering aan giro gelden is niet eens voór metaalvermeerdering verbruikt. Van 1876 tot 1901 steeg de omzet per jaar op 1 Mark deposito regelmatig van 237 Mark op 282 Mark, daarna bedroeg deze omzet:

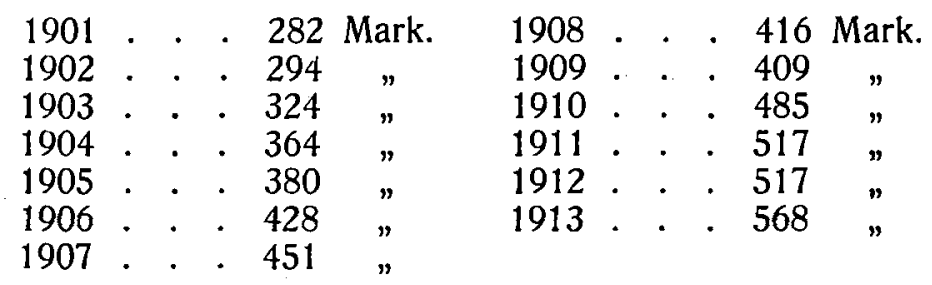

Het giro verkeer zelf heeft, zooals uit bovenstaande ciifers blijkt, eene groote uitbreiding ondergaan. Waarom het minimum der verschillende cliënten niet verhoogd is geworden, vond volgens verschillende sprekers op den Münchener Bankiersdag, zijn grond daarin, dat vooral de kleinere „Reichsbanknebenstellen", een intersiever gebruik van de Girorekening benutten om van de cliënten meer wissels ter disconteering te eischen. Al was dit laatste voor de Rijksbank voordeeliger, toch werd daardoor het streven van het Directorium te Berlijn tegengewerkt, dat eene grootere liquiditeit van de particuliere instellingen trachtte te bereiken. Reeds na de Bankenquete in 1907 en 1908 gehouden om te onderzoeken wat de oorzaken van de verzwakking der Rijksbank waren, werd een zachte druk in die richting uitgeoefend.

Waar tot nu toe de Rijksbank steeds verklaard had, aan alle beleeningsaanvragen te willen voldoen, mits deze voldeden aan de door haar gestelde eischen, daar wordt het begrijpelijk, dat b. v. een Reichsbankfähige wissel als een volkomen liquide bezit beschouwd werd, dat bovendien nog rendabel was. De meeste Berlijnsche banken beschouwden hun baargeld dan ook meer als zuiver kasgeld om aan de behoeften van den dag te voldoen, dan als reserve. De zachte druk door het Rijksbank directorium tot nu toe op de banken uitgeoefend, werd langzamerhand verscherpt, 
vooral na het najaar 1911 toen de illiquiditeit der banken de buitenlandsche politiek op ongewenschte wijze beinvloed had en de banken slechts door de ruime hulp der Rijksbank deze tijden doorgekomen zijn.

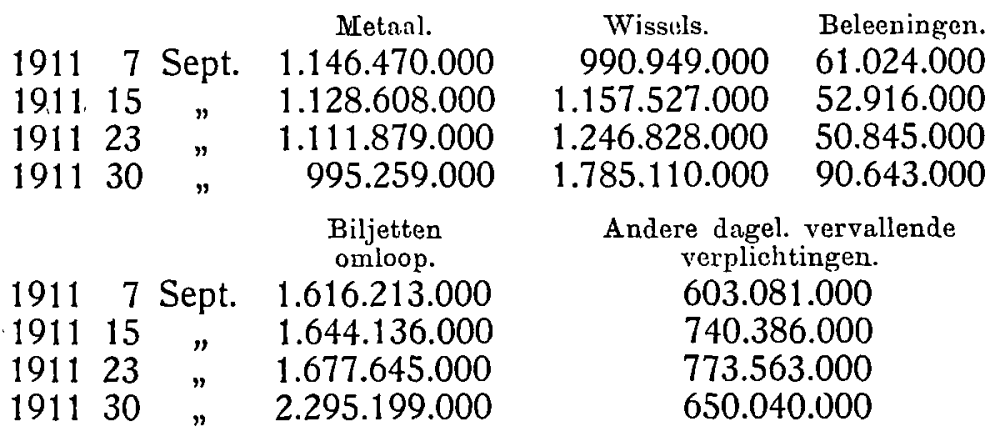

In de week van 23 op 30 September werd bijna 700.000.000 R. M. ter beschikking van het verkeer gesteld. Het disconto werd 19 September op $5 \mathrm{pCt}$. gebracht en gedurende het jaar niet meer veranderd. Al mogen politieke motieven eene verhooging eenigzins in den weg gestaan hebben, toch mag vermoed worden; dat de Rijksbank zelve niet meer zoo overtuigd was van de almacht van de discontoschroef. Naast de groote hulp door de Rijksbank verleend, maakten de banken zich meer liquide door credietopzeggingen op groote schaal. Ondanks dit alles was de toestand aanmerkelijk gunstiger dan in 1907, daar op den meest kritieken dag, de biljettenomloop nog eene metaaldekking van $43 \frac{1}{2} \mathrm{pCt}$. had, tegenover $37 \frac{1}{2} \mathrm{pCt}$. in 1907.

De druk in de richting eener groote liquiditeit van het credietwezen werd nu verscherpt, onder bedreiging van ingrijpen van den wetgever. Zelfs werd er invloed uitgeoefend op het tot stand komen van een Bankkartel, dat de banken in staat moest stellen hare conditiën tegenover hunne clienten te verhoogen, waardoor zij in staat zouden zijn grootere baarvoorraden te houden. Behalve iets uitgebreider tweemaandelijksche balansen, welke door omstreeks 100 banken openbaar gemaakt werden, hadden al deze plannen weinig merkbare resultaten.

Eindelijk, in het voorjaar van het vorig jaar, werd van de Berlijnsche grootbanken door de Rijksbank geeischt een minimum van $10 \mathrm{pCt}$. van hare dagelijks opvraagbare gelden, 
hetzij als baar 'in kas, hetzij als tegoed bij de Rijksbank, terwijl van de provinciebanken geleidelijk $8 \mathrm{pCt}$. geeischt zoude worden. Voor het verzamelen van deze $10 \mathrm{pCt}$. werd hun twee jaar gegeven.

Al kan bij dergelijk ingrijpende maatregelen niet steeds strikt logisch gehandeld worden, toch kan hierin moeilijk een zuivere lijn gezien worden. Wordt de nadruk op de grootere liquiditeit gelegd, dan moet ditzelfde niet alleen van de banken geeischt worden, maar ook van de Spar- en Genossenschaftkassen, die in tijden van crisis zeker een even groot beroep doen op de hulp der Rijksbank, als de andere banken. Is het daarentegen slechts de bedoeling, de Girogelden te verhoogen wegens het meerdere gebruik dat daarvan gemaakt wordt, dan moet dit geschieden naar maatstaf van de omzetten. Terloops zij opgemerkt, dat deze maatregel de bankconcentratie bevordert, daar slechts groote instituten in staat zijn zulk een groot deel van hunne gelden niet rendabel te laten.

Deze maatregel is diep ingrijpend genoemd. Op 31 December 1913 hadden de 9 Berlijnsche grootbanken 5148 millioen Mark aan vreemde gelden, tegenover 4919 millioen Mark op 31 December 1912, eene vermeerdering dus van 4 à 5 pCt., ongerekend hunne acceptverplichtingen. (Op 31 December 1913 bedroeg de post „Kassa, Sorten und Coupons" omstreeks 248 millioen Mark, hun kasgeld kan dus op ongeveer $3 \mathrm{pCt}$. hunner verplichtingen geschat worden.)

Hoe zijn deze gelden nu vrij te maken? Hetzij door credietopzeggingen, hetzij door de in den loop der komende twee jaar toevloeiende vreemde gelden niet meer te beleggen. Bij het uitschrijven dezer bepaling stond de Rijksbank vermoedelijk den tweeden weg voor oogen, waarbij het Bankkartel zoude moeten dienen om een deel dezer lasten door hoogere provisiën en minder rente op de deposito's aan de bankclientèle over te dragen en waarbij gerekend werd, dat de vermeerdering der vreemde gelden bij de banken in de eerst komende jaren eveneens 5 pCt. 's jaars zoude blijven bedragen.

Geen keus werd gedaan tusschen het z. g. een- of tweereserven systeem. Onder het eerste wordt toch verstaan deze toestand, waarbij alle nationale metaal reserven bij 
de circulatie bank zijn vereenigd, onder het tweede, die, waarbij de banken in' staat zijn zelfstandig door "eigen reservert en kracht aan eene crisis in den beginne het hoofd te bieden en 'pas in de tweede instantie een beroep gedaan moet worden op de hulp der circulatiebank. In het eerste geval moet de circulatiebank zelf zoo sterk zijn, door een overgroote metaaldekking harer verplichtingen, dat zij in normale tijden tevens ongevoelig wordt voor kleine conjunctuurveranderingen. Zij kan het slechts dan zijn, wanneer al het goud in den lande bij haar geconcentreerd wordt. Om daartoe te geraken zal in normale tijden de circulatiebank haar opereerend kapitaal moeten yerminderen en dan niet aan iedere credietaanvraag kunnen voldoen, ook zal zij verschil moeten maken tusschen het goud als wereldgeld en het papierengeld, de teeken en pasmunt als binnenlandsch betaalmiddel. (Deze z. g. goudconcentratie vindt in het Bank-archiv van 1 en 15 Augustus j.l. eene niet altijd even gelukkige bestrijding door dr. Fritz Huber.) In normale tijden zijn de kredietlichamen dan onafhankelijker van de Rijksbank en daardoor gedwongen eenige reserven te houden, echter in den vorm van papierengeld!: of onvolwaardige munt, welke reserve volgens eigen, natuurlijke behoefte tot stand komt.

Bij het tweede systeem worden deze reserven van hooger hand bepaald, terwijl de contrôle daarop slechts mogelijk zal zijn op de tusschentijdsche balansdagen. De totale hoeveelheid edel metaal even groot aannemend als in het eerste geval, zal de elastische uitbreiding, welke het circulatie middel in crisistijd ondergaan kan, geringer zijn. Vooral in Engeland vindt het vele voorstanders, daartoe gedrongen, door de weinige rekbaarheid van haar circulatie wezen.

In hoeverre de Rijksbank na afloop van dezen oorlog, hare eischen wijzigen zal, kan nu moeilijk voorspeld worden. De liquidatie der Dahrlehnkassen en oorlogscredietbanken zal vooreerst wel een groot deel van haar aandacht in beslagg moeten nemen.

Groote propaganda is door de Rijksbank, zoowel direct als indirect gemaakt voor baargeldsparende methoden van betaling. Hare overwegingen daartoe waren vooral, om te trachten de groote schommelingen, waaraan zoowel hare 
activa als passiva gedurende het jaar, vooral bij de driemaandelijksche termijnen, bloot stonden, te verminderen.

Als uitvloeisel van de propaganda trachtte zij tevens, met weinig succes, het hypotheekbetalingsverkeer,te regelen. ( $\mathrm{Na} 1911$ vindt men daarover geen gegevens meer in de verslagen, in 1910 werden 43, in 191146 betalingen op deze wijze verricht.) Alle mogelijke baargeldsparende methoden hebben in de laatste jaren eene groote uitbreiding verkregen. Alleen door de Rijksbank werden in

$$
\begin{aligned}
& 1911 \text { voor } 337.842 .693 .537 \text { R. M. } \\
& 1912 " \quad 371.193 .233 .575 " \\
& 1913 "
\end{aligned}
$$

uitbetaald en gestort op haar Girokonto.

Door de groote uitbreiding welke deze methoden genomen hebben, trzedt het geld steeds meer op als waardemeter en minder als ruil- en betaalmiddel of als bewaarder van waarde. Grootere sommen vloeien daardoor naar de banken als deposito's om deze betalingen te kunnen volbrengen. Deze gelden zijn echter juist de meest beweeglijke, n.l. die, welke vroeger de kasgelden vormden.

Hoe groot de uitbreiding ook zij, welke deze betalingsmethoden genomen hebben, steeds blijven er betalingen over, welke of niet door anderen gecompenseerd kunnen worden, of steeds in baar verricht moeten worden. Deze betalingen dringen zich vooral aan de kwartalen te samen en kunnen alleen gedaan worden door opvragingen der deposito's. Om daartoe in staat te zijn, zijn de kredietinstellingen genoodzaakt in laatste. instantie een beroep op de Rijksbank te doen. Op zulke termijnen is er dus een grootere hoeveelheid aan betaalmiddel noodig dan anders.

Ook in een ander opzicht hebben deze betalingsmethoden een grooten invloed op den toestand der Rijksbank. De betalingen van cheques, overschrijvingen enz. vinden voornamelijk plaats in het gebied, loopende over sommen, grooter dan 100 Mark en juist dit is het gebied, waar alleen het bankbiljet heerscht, met uitsluiting van het goud. Aan de Rijksbank wordt dus een der middelen ontnomen om haar biljetten in omloop te brengen en te houden. Al geeft de Rijksbank tegenwoordig ook biljetten, kleiner dan 100 Mark uit, toch mag dit nadeel niet door haar over 
het hoofd gezien worden. De cheques en dergelijke betalingsmiddelen vinden geen weerklank in hare balansen, zoodat ook hare biljettencirculatie een geringere waardemeter van den algemeenen toestand voor haar wordt.

Verhoogd zij hare Girogelden naar evenredigheid van de steeds vermeerderende omzetten, dan dragen tenminste de geldsparende betaalmethoden er toe bij om haar grooter weerstandsvermogen te geven.

Dat deze propaganda uit oeconomisch opzicht moet toegejuicht worden, behoeft in een tijdschrift als dit is, gelukkig niet meer uiteengezet te worden.

In een serie artikelén in het Bank-archiv heeft de Geheimer Oberfinanzrat Dr. Karl von Lumm een groot deel van de oorzaak van het mislukken van de disconto politiek in de concurrentie van de open geldmarkt gezocht en om dit te voorkomen : wil hij trachten deze open geldmarkt te bewegen de Rijksbank niet te onderbieden, terwijl hij ook een steeds grooter deel van den wisselomloop door handen van de Rijksbank wil laten gaan. Of dit ooit mogelijk za zijn is twijfelachtig.

Gemiddeld Disconto:

$1903 \quad 1904 \quad 190519061907 \quad 1908190919101911 \quad 1912 \quad 1913^{\circ} 1914$ Rijksb. $\begin{array}{llllllllllll}3.84 & 4.22 & 322 & 5.15 & 6.03 & 4.76 & 3.92 & 4.35 & 4.40 & 4.95 & 5.88 & 4.15\end{array}$

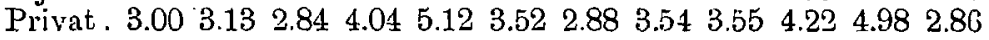
$\begin{array}{lllllllllllllll}\text { Verschilo.84 } & 1.09 & 0.38 & 1.11 & 0.91 & 1.2 & 1.04 & 0.81 & 0.85 & 0.73 & 0.90 & 1.29\end{array}$

Het privaat disconto is steeds in zeer labiel evenwicht, ontstaan door de dagelijksche vraag en aanbod en daardoor zeer gevoelig voor alle oogenblikkelijke invloeden als emissiën en dergelijken.

Het beste middel om Bank en privaatdisconto zooveel mogelijk te laten overeenstemmen, is een mindere zakenlust bij de Rijksbank d.w.z. het laten voorbijgaan van dat materiaal dat zich voor het privaatdisconto beter eigent, waardoor op de open markt eerder een toestand van verzadiging intreedt. Wanneer de Bank dan tevens diegenen aan eene strengere keuring onderwerpt, die tot direct verkeer met haar toegelaten worden en te zijner tijd wissels, die overigens bankfähig zijn, weigert te disconteeren, dan zal de spanning tusschen beiden ook verminderen. Bij de beoordeeling over het al dan niet disconteeren van wissels, 
moet zij niet alleen rekening houden met de soliditeit der handteekeningen, maar vooral met de omstandigheden, die het wellicht wenschelijk maken het kredietverkeer in te perken. Zij moet van haar invloed gebruik maken om het kredietverkeer binnen de gewenschte grenzen te houden. Angst voor verminderden invloed door een minderen wisselomzet behoeft eene circulatiebank niet te hebben, vooral niet daar het privaatdisconto nimmer in al te groote mate van het officieel disconto zal kunnen afwijken. Niet alleen omdat het privaat disconto slechts voor zeer bepaalde wissels geldt, maar ook door het feit, dat een wissel beneden het bankdisconto gekocht, minder spoedig naar de centrale bank gebracht zal worden en dus een groot deel harer liquiditeit moet inboeten.

Verschillende schrijvers willen de Bank het verschil tusschen Privaat- en Markt-disconto desnoods laten uitnutten om op de open markt wissels te herdisconteeren, zooals tot nu toe met schatkistbiljetten gebeurde. Al zijn er volgens de algemeen gangbare begrippen bezwaren aan verbonden om een bank, die over gratis middelen beschikt, nog geld tegen rente te laten opnemen, toch gebeurt dit geldopnemen juist om dat gratis kapitaal niet sterker in beslag te doen nemen dan hoog noodig is.

Toch schijnt de Rijksbank afgezien te hebben van het streven om bank- en privaatdisconto te laten overeenstemmen. Toen zij in Februari van het vorig jaar haar disconto tot $4 \mathrm{pCt}$. verlaagde, gaf zij tevens officieus te kennen, niet voornemens te zijn om voorloopig haar disconto verder te verlagen, ondanks de toenmalige groote marge met het privaatdisconto.

Naast de hierboven beschrevene maatregelen, zijn er nog tal van andere, groot en klein, toegepast of slechts voorgesteld, om de positie der Rijksbank te versterken. Van deze kunnen nog als de voornaamste genoemd worden:

1. Het maken der bankbiljetten tot een wettig betaalmiddel. (1907)

2. De verzwaring van de beleeningsvoorwaarden op de kwartaalstermijnen.

3. De concentratie van alle Rijks- en Staats- kassaldo's bij de Rijksbank. (niet toegepast.)

en nog vele andere. 
In het kort kan de politiek der Rijksbank van de laatste jaren aldus samengevat worden:

1. Streven naar credietinperking in normale tijden, om in staat te zijn in crisistijden ruim hulp te bieden en daardoor het particuliere kredietwezen in gewone omstandigheden minder op haar hulp te doen steunen.

2. Streven naar versterking van haren metaalvoorraad en daardoor bewust of onbewust, werkende in de richting der goudconcentratie.

Groote middelen om hare positie te versterken heeft $\mathrm{zij}$ niet toegepast, indachtig aan het groote gevaar verbonden aan het ruw ingrijpen in ingewikkelde oeconomische ver-houdingen. Zij heeft dus niet haar kapitaal verhoogd, niet eene plotselinge verandering en grootere liquiditeit van het kredietverkeer geeischt, maar heeft bedachtzaam eene opvoedende politiek trachten toe te passen, waardoor zij op $23 \mathrm{Juli}$ j.l. in eene sterkere positie verkeerde dan in jaren het geval geweest was. Ontkend kan niet worden, dat de latente crisis waaraan Duitschland sedert 1911 geleden heeft, de algemeene kredietaanvraag verminderd heeft en daardoor metaal naar de kluizen der Rijksbank heeft doen vloeien.

In 1913 geven de verschillende getallen hierboven aangehaald een opgewekter beeld, dan in jaren het geval geweest was. Met eene gouddekking van ruim $49 \mathrm{pCt}$. harer opvraagbare gelden, had dit goud in Juli j.l. een ongekende hoogte bereikt; reeds in November 1913 had de Rijksbank voor het eerst meer dan anderhalf Milliard metaal in haar bezit.

De groote economische crisis, welke Duitschland op het oogenblik doormaakt, had moeilijk onder gunstiger auspiciën ingezet kunnen worden, voor zooverre het de positie harer voornaamste circulatiebank aangaat.

Rotterdam. Jhr. F. W. L. DE BEAufort.

Naschrift.

Sedert bovenstaande regelen geschreven werden heeft de toestand in Duitschland zich meer ontwikkeld en kan eenigzins nagegaan worden in hoeverre de goudpolitiek der 